\title{
A Comparative Analysis of the GSDP of the Four Eastern States of India
}

\author{
Anil Bhuimali ${ }^{1}$ and Mukul Saha ${ }^{2}$ \\ ${ }^{1}$ Vice-Chancellor, Raiganj University, Raiganj, West Bengal, India \\ ${ }^{2}$ Associate Professor, Prabhu Jagatbandhu College, Howrah, West Bengal, India \\ E-Mail: mukulsaha1406@gmail.com
}

\begin{abstract}
In this paper entitled "A Comparative Analysis of the GSDP of the Four Eastern States of India" we will compare the GSDP of the four eastern states of West Bengal, Bihar, Odisha and Jharkhand, their status in relation to some economically more developed states like Maharashtra, Gujarat and Tamil Nadu and also all India. The paper focuses on the development perspective of these states essentially with reference to the Gross State Domestic Product (GSDP). The Gross State Domestic Product of a state comprises of the primary sector, secondary sector and the tertiary sector. Agriculture, forestry, mining and fisheries are the primary sector. But in our study we have considered only agriculture and excluded the allied activities. Industrial and manufacturing comprise of the secondary sector. In the tertiary sector we find services like IT, banking and all other services which are not included in the primary and secondary sectors. In this paper we discuss the Gross State Domestic Product of the four eastern states which is the main pillar of a state's economy.
\end{abstract}

Keywords: Gross State Domestic Product (GSDP), Gross Domestic Product (GDP), demography, agriculture, industry, service sector

\section{INTRODUCTION}

In this paper entitled "A Comparative Analysis of the GSDP of the Four Eastern States of India", we will compare the GSDP of the four eastern states of West Bengal, Bihar, Odisha and Jharkhand, their status in relation to some economically more developed states like Maharashtra, Gujarat and Tamil Nadu and also all India. The paper focuses on the development perspective of these states essentially with reference to the Gross State Domestic Product (GSDP).

\section{GSDP: A COMPARATIVE ANALYSIS}

The economic development of any state depends on the GSDP of that state and so we focus on the discussion of the GSDP of these states. Further, the economy of any state depends to a great extent on the demography of the state. So before moving on to discuss the GSDP we first study some important selective features of demography for a comparative analysis. Table I gives us the density of population, total population and the area of the states as per 2001 and 2011 census.

TABLE I DEMOGRAPHY

\begin{tabular}{|l|c|c|c|c|c|c|}
\hline \multicolumn{1}{|c|}{ Demographic Criteria } & States /Year & West Bengal & Bihar & Odisha & Jharkhand & All India \\
\hline \multirow{2}{*}{$\begin{array}{l}\text { Density of Population (per square km) } \\
\text { (Growth Rate) }\end{array}$} & 2001 & 903 & 881 & 236 & 338 & 325 \\
\cline { 2 - 7 } & 2011 & $\begin{array}{c}1028 \\
(13.80 \%)\end{array}$ & $\begin{array}{c}1106 \\
(25.50 \%)\end{array}$ & $\begin{array}{c}270 \\
(14.40 \%)\end{array}$ & $\begin{array}{c}414 \\
(22.50 \%)\end{array}$ & $\begin{array}{c}382 \\
(17.50 \%)\end{array}$ \\
\cline { 2 - 7 } & 2011 & 77.08 & 63.82 & 72.87 & 66.41 & 74.04 \\
\hline \multirow{2}{*}{ Total Population(in thousands) } & 2001 & 80176 & 82999 & 36805 & 26,946 & 1028737 \\
\cline { 2 - 7 } & 2011 & 91276 & 104099 & 41974 & 32,988 & 1210855 \\
\hline Area( in square km) & $2001 / 2011$ & 88752 & 99200 & 155820 & 79714 & 3287263 \\
\hline
\end{tabular}

We see in table 1 that the area of Odisha (155820 sq.km) is the highest among the four eastern states of our study, whereas its population is the second lowest (41974000) in the year 2011. Consequently we find that the density of population of Odisha is the lowest (270 per sq.km). In case of Bihar (1106 per sq. km) the density of population is the highest amongst the four states followed by West Bengal (1028 per sq. km) and lastly Jharkhand (414 per sq. km) in the year 2011.
In case of all India the density of population is 382 per sq.km in the year 2011. Density of population of Bihar is nearly three times than the all India figure, whereas West Bengal is more than two and half times of all India. This is detrimental for the economy of these two overpopulated states and it is a hindering factor in the development of these states. Since area of a state is fixed so increase in population results in increase in density of population. Here growth rate of density of population is nothing but the 
growth rate of population of the state. An interesting point to be noted in the table 1 is that in the period 2001-2011 the growth rate of density of population is the highest in Bihar (25.5\%), whereas in case of Jharkhand it is $22.5 \%$. Comparing this with all India figure (17.5\%) it is seen that the growth rate of Bihar and Jharkhand are much higher than all India, whereas West Bengal (13.8\%) and Odisha (14.4\%) are less than the all India figure.

Bihar's density of population as well as total population is quite high. Moreover its growth rate of population is also very high. This implies that Bihar has failed miserably to control its population growth. We see in the table 1 that Bihar (10.4 crores) has the highest population amongst the four eastern states followed by West Bengal (9.1 crores), Odisha having only 4.2 crores and the lowest is Jharkhand having a population of 3.3 crores in the year 2011. Population has a great impact in the per capita analysis. So we may say that population is a determining factor in the economic health of a state. Now we move on to discuss the Gross State Domestic Product which is the main pillar of a state's economy. In this paper we compare the four eastern states with some of the more economically developed states like Maharashtra, Gujarat, and Tamil Nadu to see how far behind are the eastern states.

Table II gives the GSDP of each state at current price with base year 2004-2005 and also as a percentage on GDP. This table has been diagrammatically represented in Figures 1 and 2.

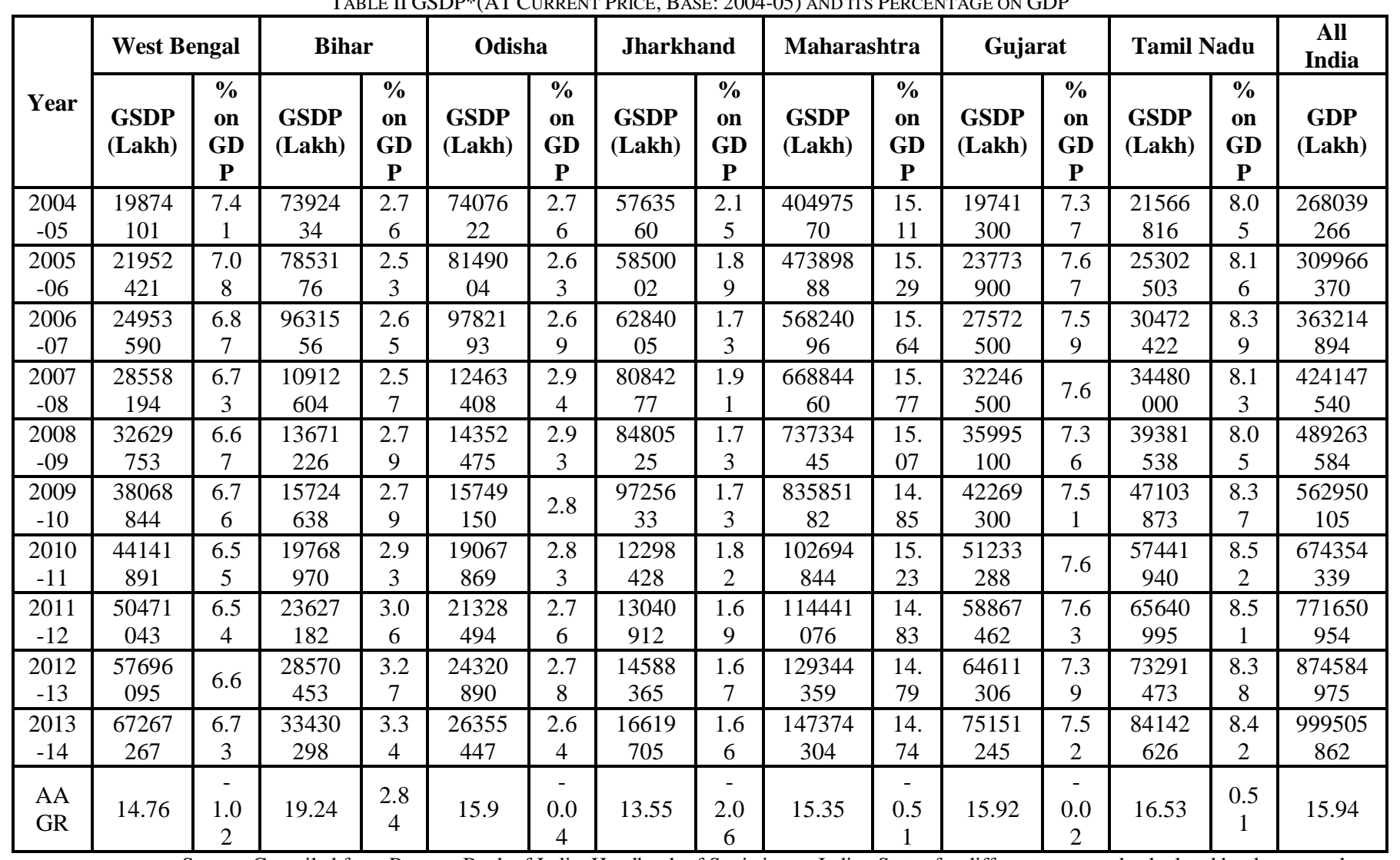

Source: Compiled from Reserve Bank of India, Handbook of Statistics on Indian States for different years and calculated by the researcher. * Note: Here GSDP does not include the allied activities like fishery, forestry etc. in agriculture

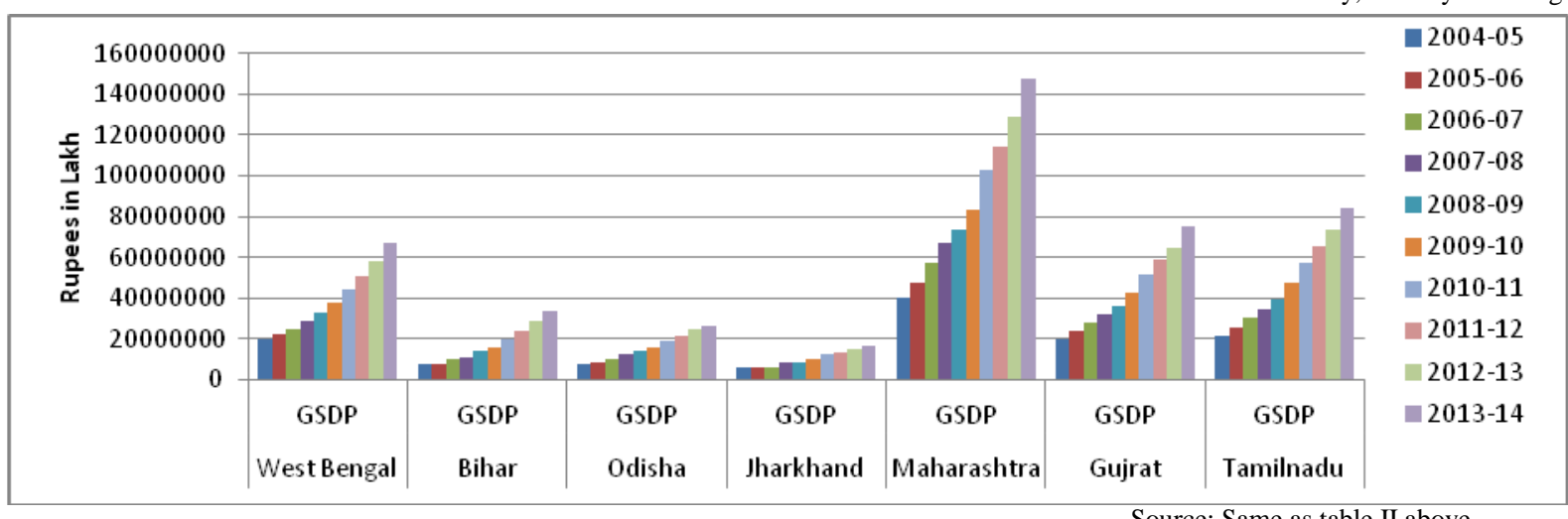

Fig.1 Gross State Domestic Product (at Current Price, Base: 2004-05) 
In figure 1 we see that the GSDP of all the seven states has increased over the period 2004-05 to 2013-14. Among the four eastern states West Bengal has the highest GSDP followed by Bihar, Odisha and the lowest is Jharkhand.
Comparison of the eastern states with the developed states of Maharashtra, Gujarat and Tamil Nadu shows that the economic condition of the eastern states is miserable compared to them.

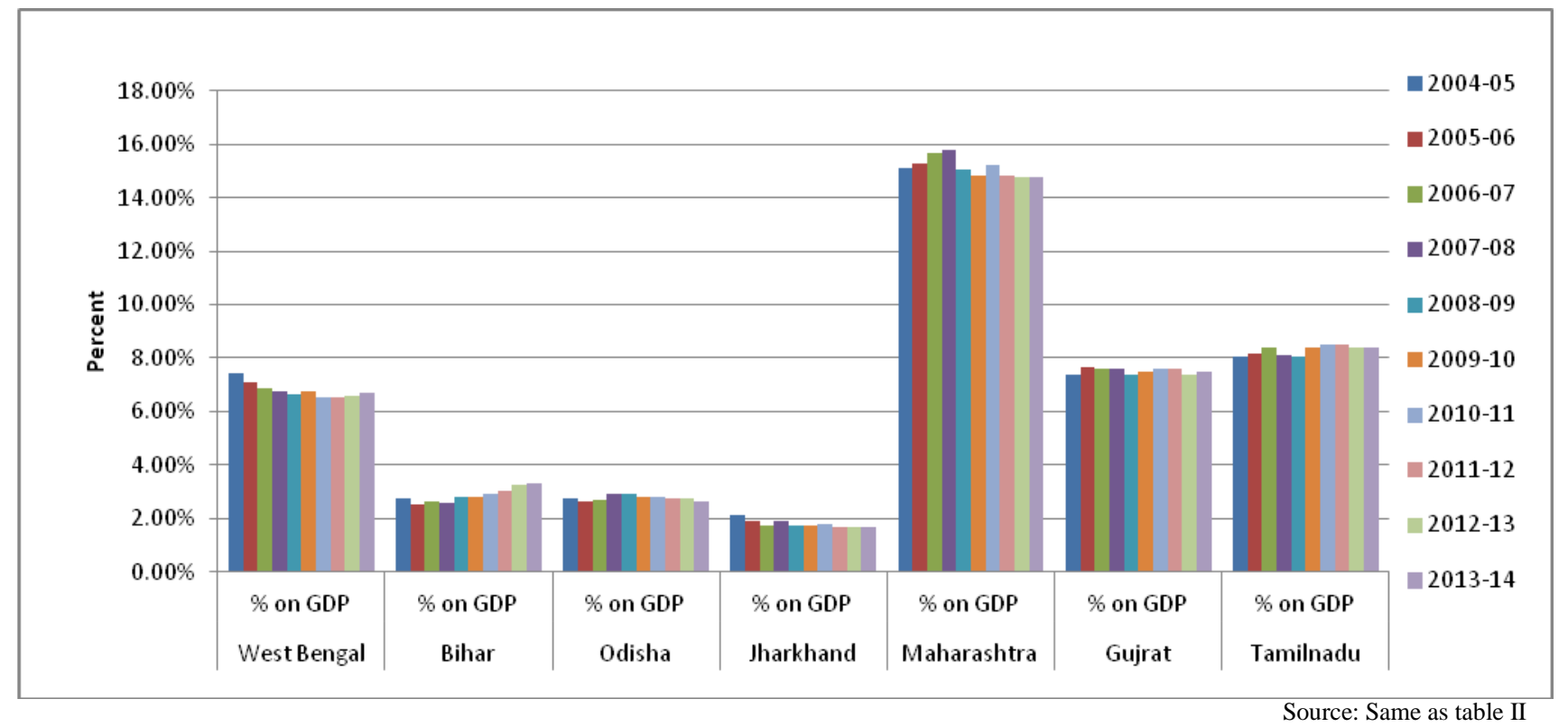

Fig. 2 GSDP as \% on GDP

Fig. 2 represents the contribution of GSDP towards GDP. Contribution of GSDP of West Bengal towards GDP during the period 2004-05 to 2013-14 ranges from $7.41 \%$ to $6.54 \%$ having a negative AAGR of -1.02. Contribution of GSDP of Bihar towards GDP during this period ranges from 2.53\% to $3.34 \%$ having a positive AAGR of 2.84. In case of Odisha it ranges from $2.94 \%$ to $2.63 \%$ having a negligible negative AAGR of -0.04; in case of Jharkhand it ranges from $2.15 \%$ to $1.66 \%$ having a huge negative AAGR of -2.06 .

From table 2 it is seen that the AAGR of GSDP in absolute terms of West Bengal is 14.76, of Bihar it is 19.24, of Odisha it is 15.90 , of Jharkhand it is 13.55 , of Maharashtra it is 15.35, Of Gujarat it is 15.92 and of Tamil Nadu it is 16.53. Whereas it is seen that AAGR of GDP is 15.94. Among the four eastern states only Bihar has a greater growth rate than the growth rate of GDP.

So, we may conclude that though there are many hindering factors of development in Bihar which has faced a loss of natural resources and industries during bifurcation to Jharkhand, it is highly overpopulated, nevertheless, its growth rate of GSDP is greater than that of GDP. This is a remarkable achievement of the present government of Bihar and is highly appreciable.

From Fig 1 and 2 it is quite evident that Maharashtra is quite ahead than all the other states. Even Gujarat and Tamil Nadu are better than the eastern states.
The Gross State Domestic Product of a state comprises of the primary sector, secondary sector and the tertiary sector. Agriculture, forestry, mining and fisheries are the primary sector. But in our study we have considered only agriculture as our data is based on the RBI data bank where they have excluded these allied activities from agriculture. Industrial and manufacturing comprise of the secondary sector.

In the tertiary sector we find services like IT, banking and all other services which are not included in the primary and secondary sectors. Now we make a comparative analysis of the contribution of the primary sector to the GSDP of the four eastern states.

In table III and Fig 3 we see that the agricultural contribution of West Bengal in absolute terms towards GSDP is far better than the other eastern states, followed by Bihar, Odisha and lastly Jharkhand.

In table III and fig 4 we consider agricultural contribution as a percentage on GSDP of the four states. We see that compared to other states and even all India Bihar's agricultural contribution as a percentage on GSDP is higher. This implies that in case of Bihar agriculture is one of the major contributors towards its GSDP. 
Table III Sectoral Gross State Domestic Product at Factor Cost: Agriculture CurRent Prices (BASE: 2004-05)

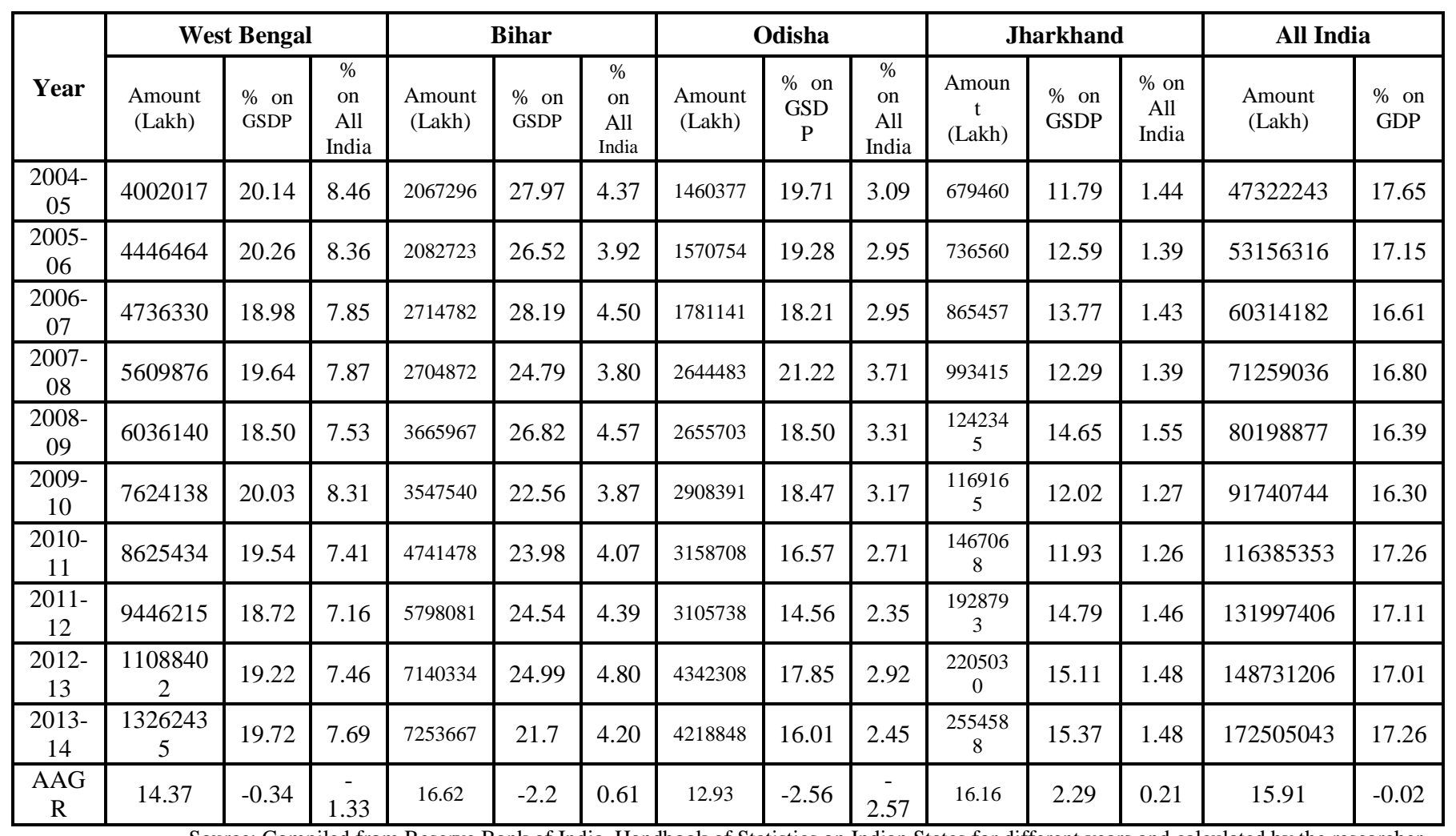

Source: Compiled from Reserve Bank of India, Handbook of Statistics on Indian States for different years and calculated by the researcher. Note: Here agriculture as a component of GSDP does not include the allied activities like fishery, forestry etc.

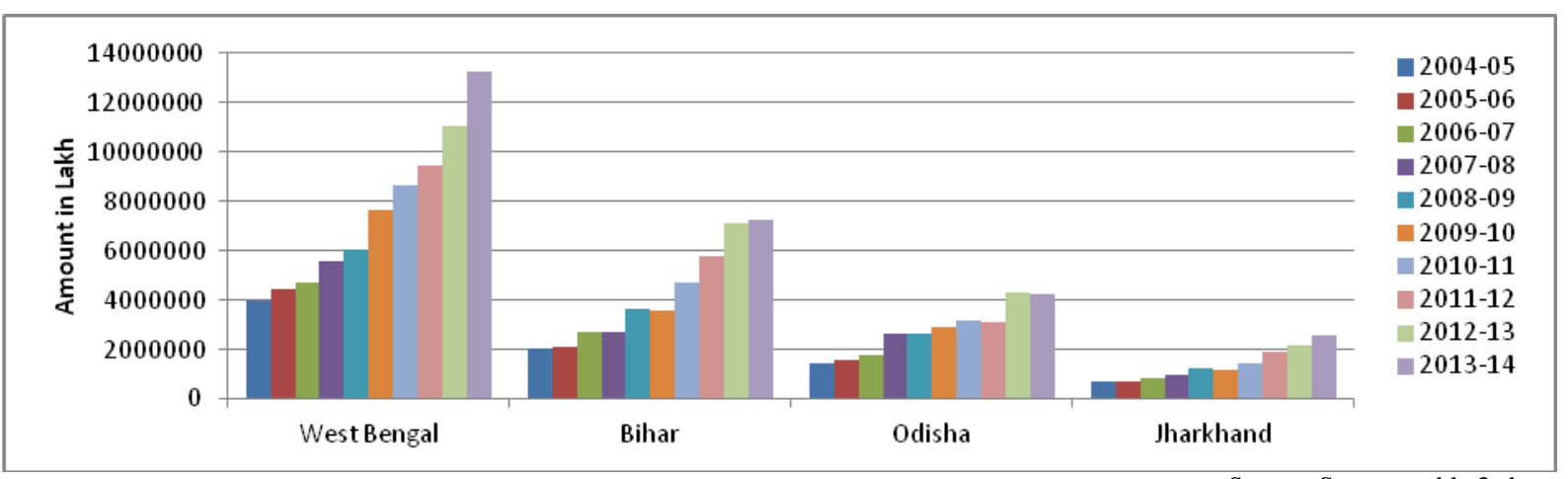

Fig. 3 Contribution of Agriculture in GSDP

Source: Same as table 3 above

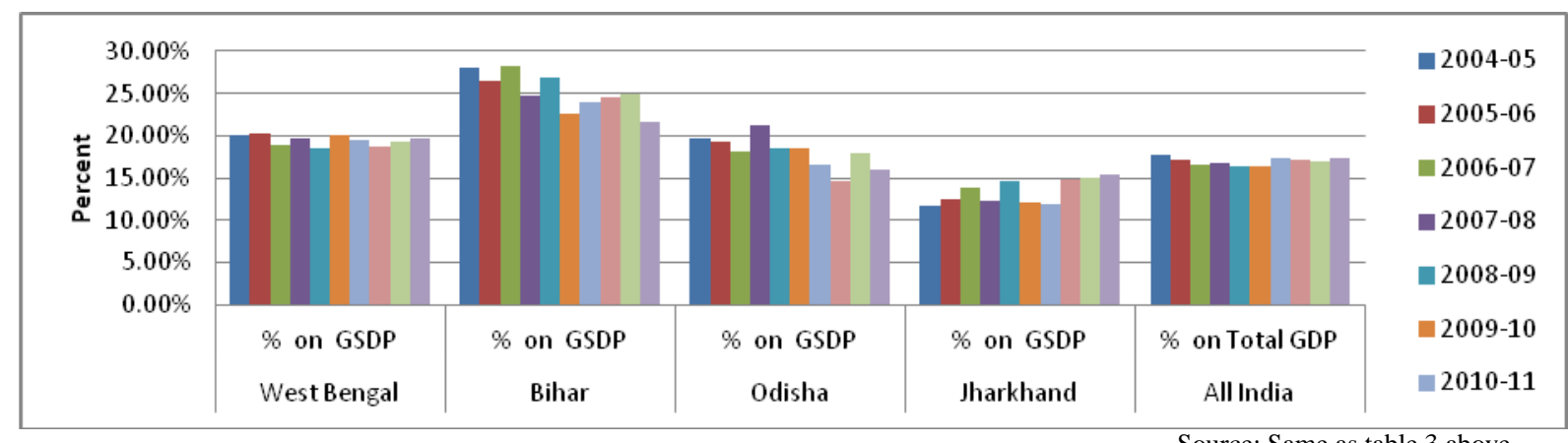

Fig. 4 Agriculture as \% on GSDP

Source: Same as table 3 above 


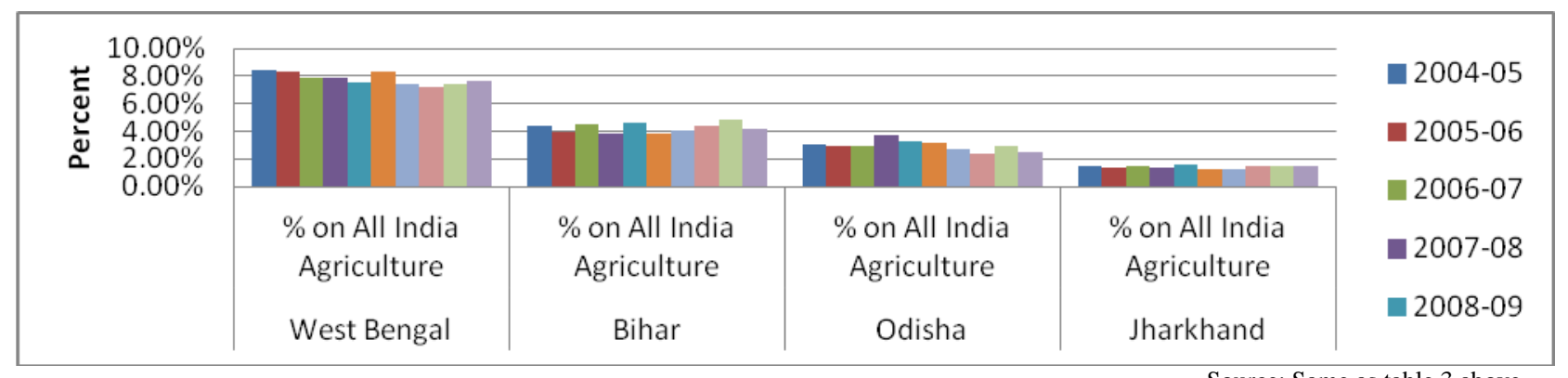

Fig. 5 Agricultural Output as \% on All India Agricultural Output

Source: Same as table 3 above

In table III and Fig 5 we see that agriculture of West Bengal as percentage on all India agriculture is the highest among the four eastern states. This is quite obvious as in Fig.3 we see that agriculture in absolute terms is the highest in West Bengal. So it is natural that the total percentage contribution of agriculture of West Bengal to all India agriculture will be the highest among the four eastern states. So West Bengal is a major contributor of agriculture to all India. From the table III it is seen that agricultural contribution of West Bengal as percentage on all India agriculture ranges from $7.16 \%$ to $8.46 \%$ during the period $2004-05$ to $2013-14$. In case of Bihar it is almost half of West Bengal ranging from $3.80 \%$ to $4.80 \%$. Odisha's contribution is much below ranging from $2.35 \%$ to $3.71 \%$. Lastly Jharkhand has the lowest contribution ranging from $1.26 \%$ to $1.48 \%$ which is a marginal figure.

When we consider the AAGR of agricultural contribution in absolute terms we see that all the states as well as all India have positive figures and are close on the heels except Odisha whose performance is a bit poor. Considering the AAGR of agriculture as percentage on GSDP we see that except Jharkhand all the other states as well as all India have negative figures. But the all India figure is marginally negative $(-0.02)$ which cannot be termed as negative in the real sense. Bihar (-2.20) and Odisha (-2.56) have negative AAGR implying that they have greater positive contribution towards GSDP in either industry or service sector or both. West Bengal (-0.34) has a negligible negative figure.

Considering the AAGR of agriculture as percentage on all India agriculture we see that except Jharkhand and Bihar the other two eastern states of West Bengal and Odisha have negative AAGR. This means that all India agricultural contribution of West Bengal and Odisha has been decreasing over the years. This again implies that some other agriculturally developed states fill up this gap.

TABLE IV SECtoral Gross State Domestic Product at Factor CoST: INDUSTRY AT CURRENT PRICES (BASE: 2004-05)

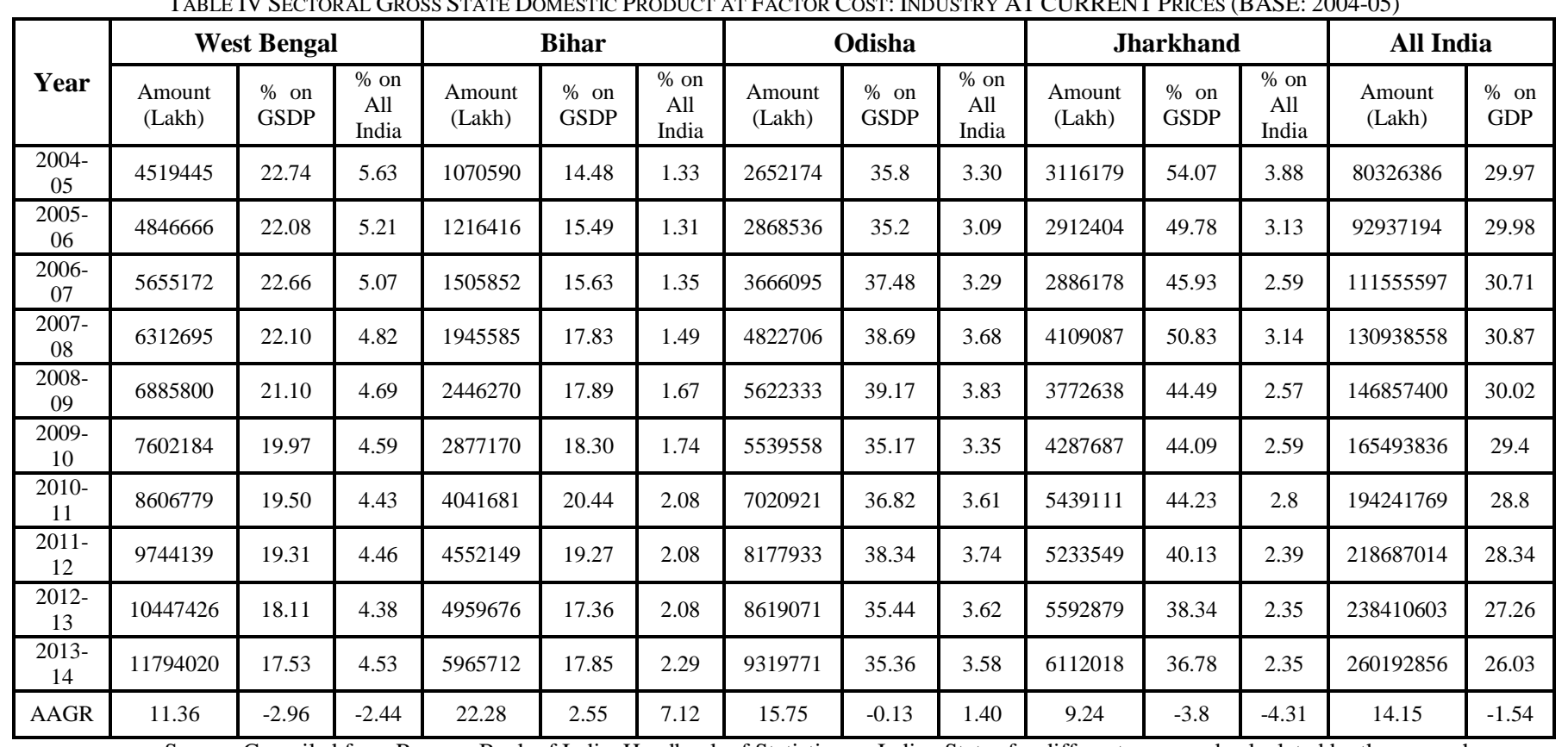

Source: Compiled from Reserve Bank of India, Handbook of Statistics on Indian States for different years and calculated by the researcher. 


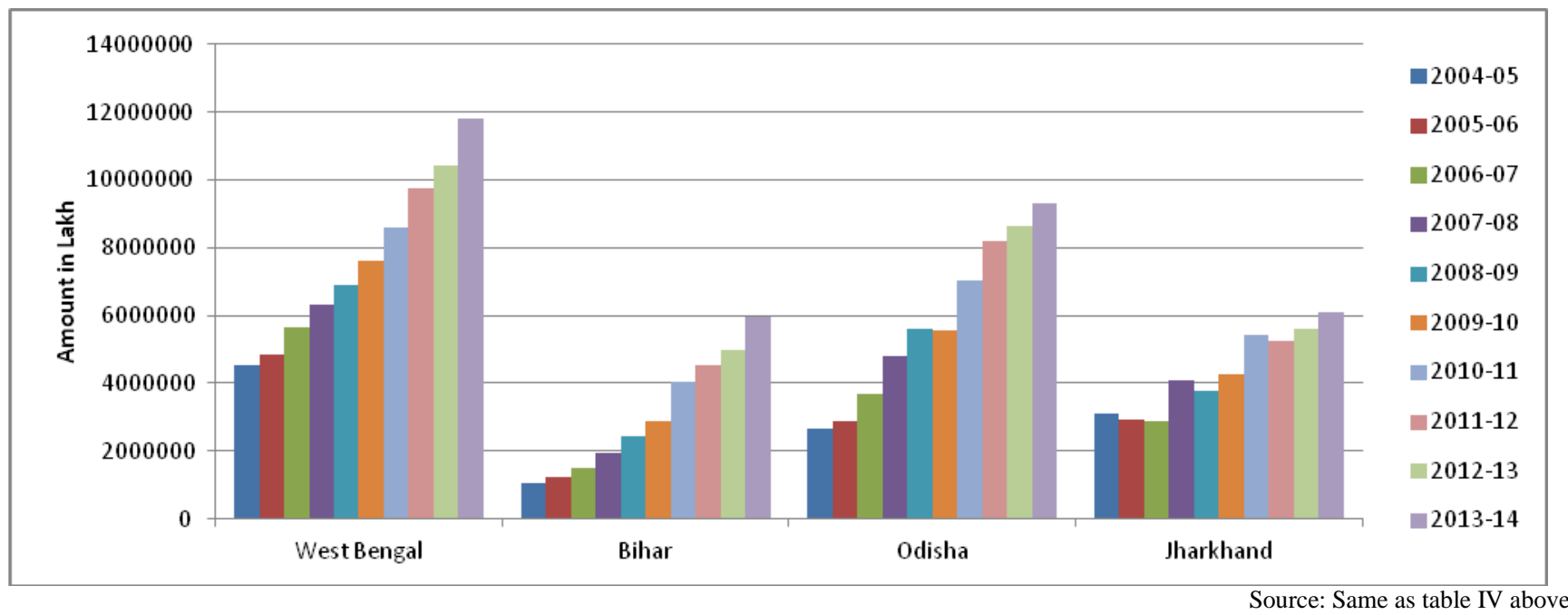

Fig. 6 Contribution of Industry in GSDP

From table 4 and figure 6 it is clearly evident that West Bengal supersedes other three eastern states in industrial contribution towards GSDP in absolute terms. Odisha ranks second followed by Jharkhand and lastly Bihar. Though Bihar ranks the last in industrial contribution towards GSDP in absolute terms, nevertheless, it has an extraordinarily high AAGR (22.28) due to its rapid industrial development. The other three states are much behind Bihar where West Bengal has an AAGR of 11.36, Odisha has 15.75, Jharkhand has 9.24 and the all India figure is 14.15 .

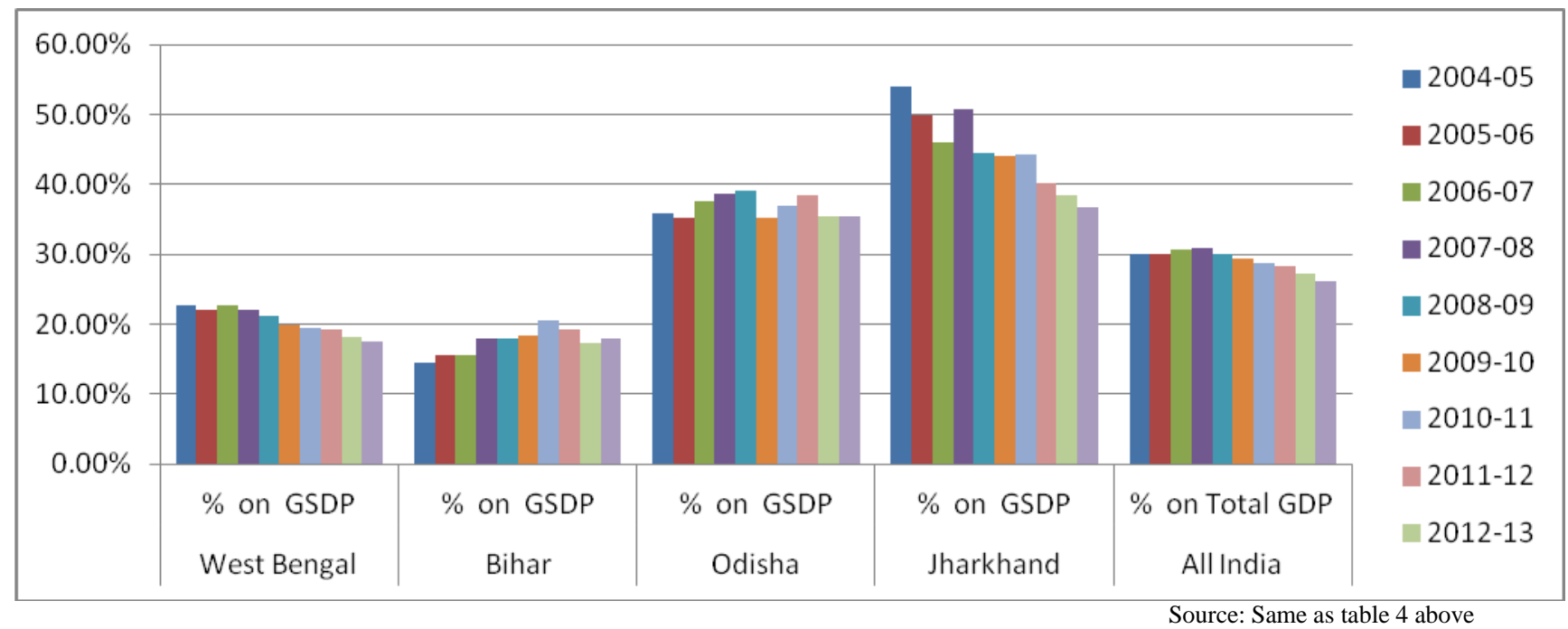

Fig. 7 Contribution of Industry as \% on GSDP

Considering the contribution of industry as percentage on GSDP, we see that Jharkhand is in a leading position compared to other states and even all India. During the time of bifurcation of Bihar Jharkhand was created with most of the state's industries and natural resources. But due to various factors like poor industrial policy, corruption and inefficient governance Jharkhand could not maintain its industrial growth. Consequently, we see that Jharkhand has a highly negative AAGR (-3.80) when we consider the industrial contribution as a percentage on GSDP. If this continues then the economy of Jharkhand will collapse in the near future. In this regard Odisha is less than Jharkhand but greater than all India and the other two eastern states of West Bengal and Bihar with West Bengal in the third position. Considering West Bengal's AAGR of industrial contribution as a percentage on GSDP it is highly negative
(-2.96). If this negative growth rate continues then the economy of West Bengal will be in trouble. West Bengal government must focus on this issue urgently and concretely adopt a positive industrial policy to attract investors. The state government should adopt a favorable land acquisition policy so that investors are attracted into establishing new industries. Bihar is in the lowest position regarding industrial contribution as a percentage on GSDP. But on the contrary, due to the government's efficient industrial policy and sincere efforts of the present government towards industrial development it is seen that Bihar has a high positive AAGR (2.55). Except Bihar all other states as well as all India have negative AAGR in relation to industrial contribution as a percentage on GSDP. This is really remarkable on the part of the present government of Bihar. 


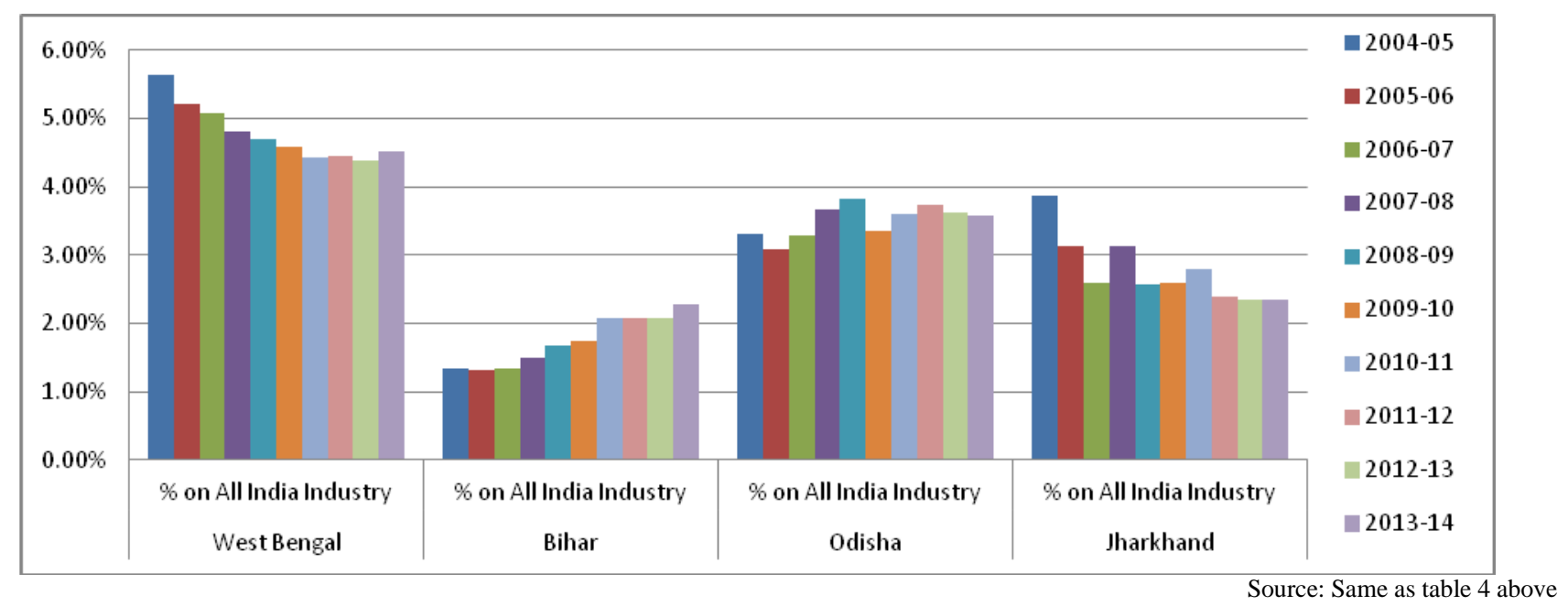

Fig-8: \% on All India Industry

Considering the industrial contribution as percentage on all India industry, from table 4 and Fig 8 it is evident that West Bengal contributes the highest percentage ranging from $4.38 \%$ to $5.63 \%$ towards all India industry, among the four eastern states. In Fig. 6 we have already seen that West Bengal ranks the highest in industrial contribution in absolute terms. So it is obvious that all India percentage share of West Bengal will also be high. Following West Bengal, second in rank is Odisha followed by Jharkhand and lastly Bihar.

Considering the AAGR as percentage on all India industry, we find that Bihar's AAGR is a mammoth figure of 7.12, something remarkably positive. As we have already mentioned in Fig.5 that this striking AAGR is due to the government's industrial policy and sincere efforts of the present government towards industrial development. Odisha comes at a distant second at 1.4 whereas the other two states of West Bengal and Jharkhand have a negative AAGR of 2.44 and -4.31 respectively. This implies that the states of West Bengal and Jharkhand are walking backwards with regard to industrial growth.

Now we move on to the service sector to compare the contribution of service sector towards GSDP of four eastern states. The service sector, also called the tertiary sector covers a wide range of activities ranging from services which are provided by different sectors. They include the most sophisticated sectors like tele-communication, satellite mapping and computer software; simple services provided by the unskilled menial workers like the barbers, the plumbers and the carpenters; highly capital intensive activities like civil aviation and shipping; employment oriented activities like tourism, real estate, and housing; infra-structure related activities like railways, roadways and ports to social related activities like health and education.

The four eastern states of India of our study have a number of problems which are socio economic in nature. Poverty and accelerated population growth are major constraints, thereby depriving several people of access to basic health and education. A number of obstacles hamper the progress of this sector and its contribution to inclusive growth. Bureaucratic inertia, multiple government bodies having their own sets of rules and regulations, rampant corruption and absence of a uniform concrete policy have an adverse effect on the system.

Slow reform process, restrictions on foreign direct investment, poor infrastructural facilities, absence of uniformity in the quality and standard of education, in spite of having renowned Brain Power and the existence of unemployable educated youth are all limiting factors. India, however, has vast potential for promotion of service economy. This is attributed to factors such as emergence of a new middle class with increasing aspirations, opening of the economy leading to the availability of a wide range of goods and services, growing retail and improving domestic and international market for Information Technology.

From National Industrial Classification, 2008 [Central Statistical Organisation, Ministry of Statistics and Programme Implementation (MOSPI), Government of India], it may be contended that the service sector comprises of Wholesale and retail trade; repair of motor vehicles and motorcycles, transportation and storage, accommodation and food service activities, information and communication, financial and insurance activities, real estate activities, professional, scientific and technical activities, administrative and support service activities, public administration and defence; compulsory social security, education, human health and social work activities, arts, entertainment and recreation, activities of households as employers; undifferentiated goods and services producing activities of households for own use and activities of extraterritorial organisations and bodies. 
Table V Sectoral Gross State Domestic Product at Factor Cost: Service at CuRrent Prices (BASE: 2004-05)

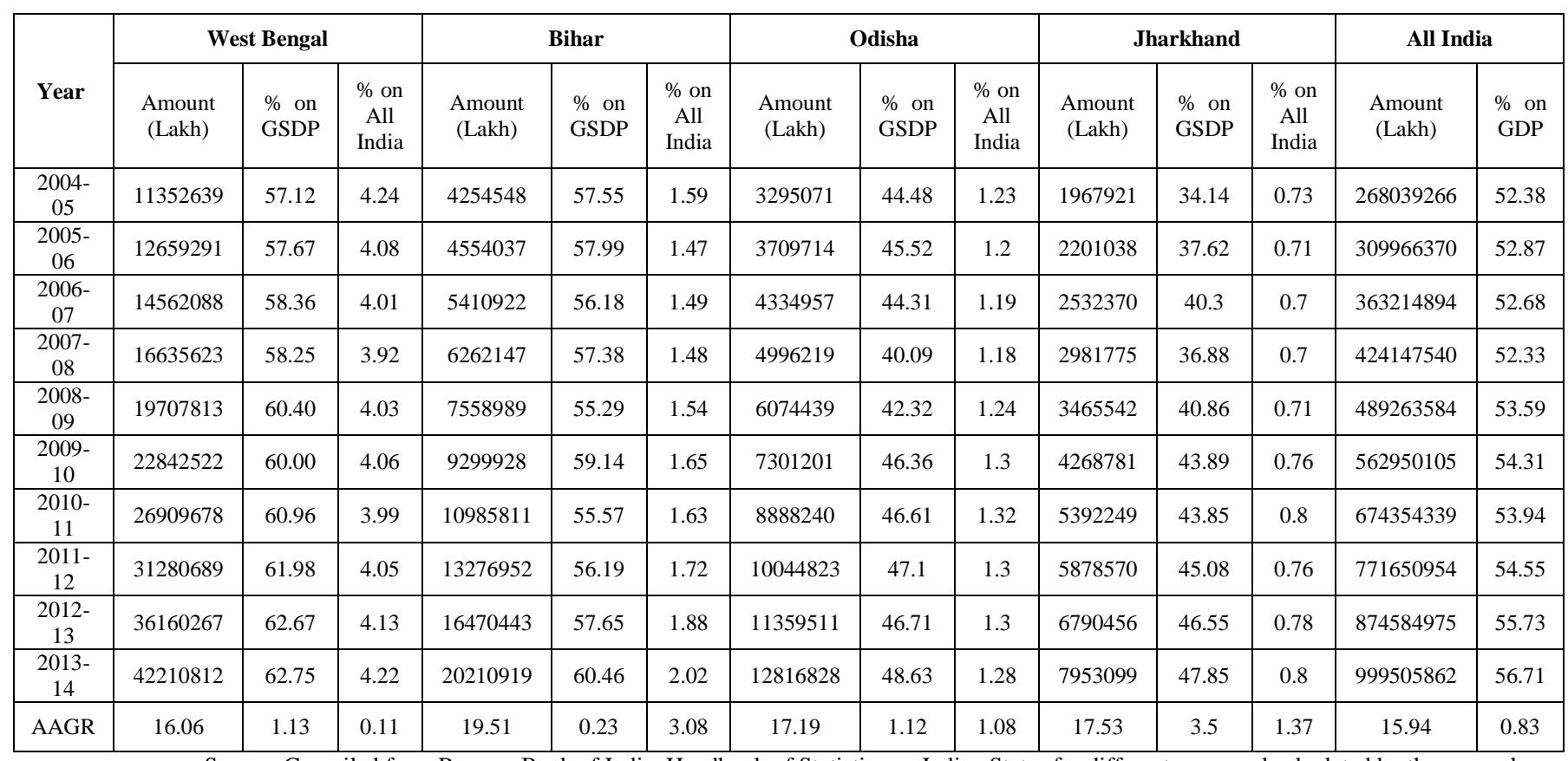

Source: Compiled from Reserve Bank of India, Handbook of Statistics on Indian States for different years and calculated by the researcher.

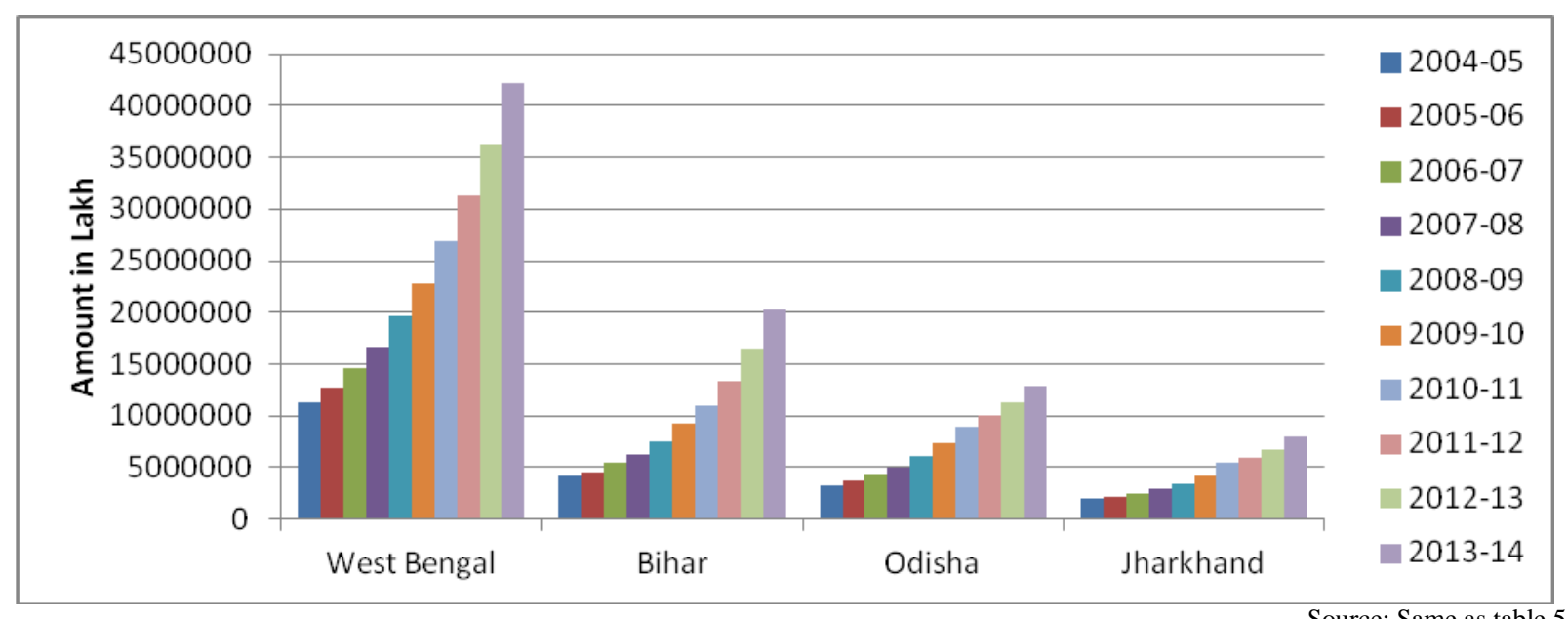

Fig. 9 Contribution of Service Sector in GSDP

Source: Same as table 5 above

Table $\mathrm{V}$ and Fig. 9 reflects the contribution of service sector towards GSDP in absolute terms. It is seen that as in previous cases even in this case West Bengal is ahead of the other three states followed by Bihar, Odisha and lastly Jharkhand. If we consider the AAGR in absolute terms we see that as before Bihar ranks the highest with an AAGR of
19.5. It is noteworthy that the AAGR of Bihar in agriculture, industry and service in absolute terms is very high and supersedes the other three states and all India. Though total GSDP is a low figure, yet, since its growth rate is high the state has every possibility of rapid development. 


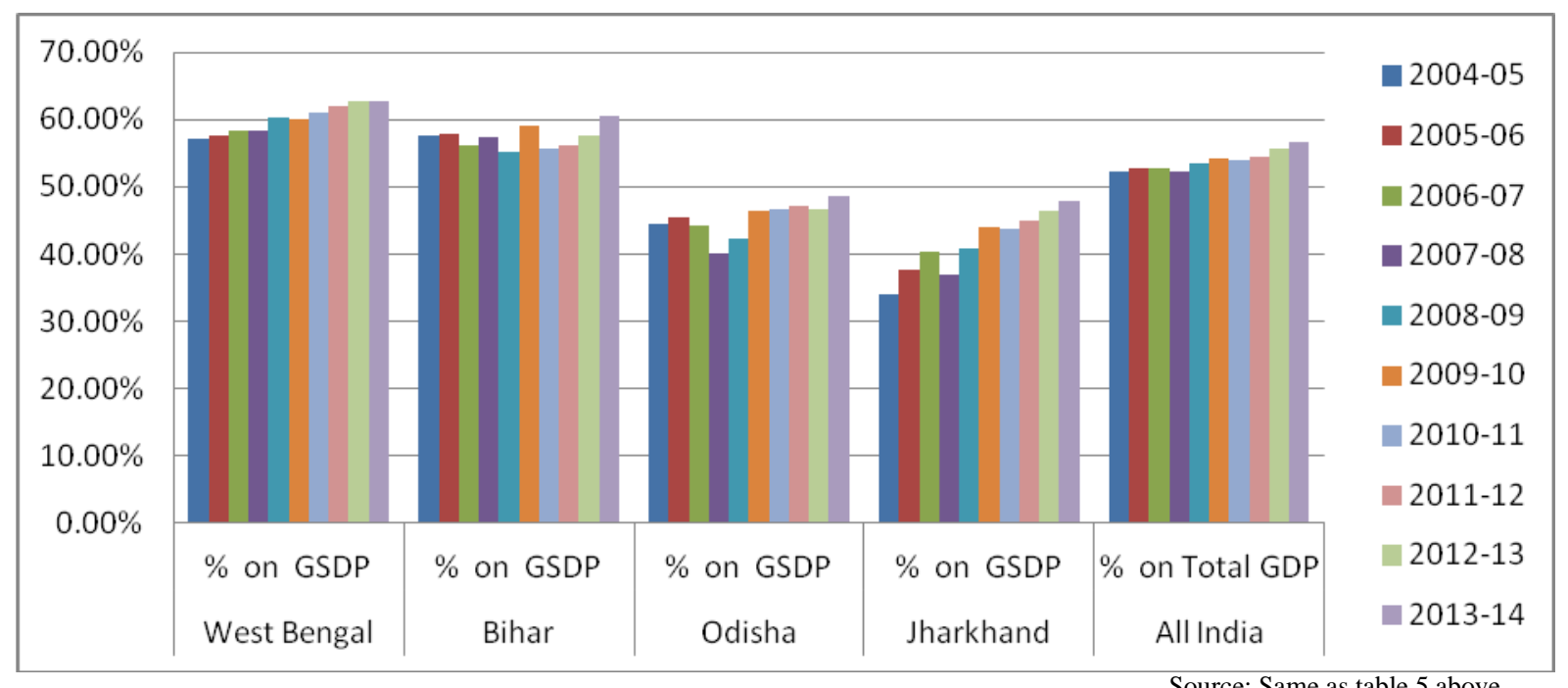

Fig. 10 Contribution of Service Sector as \% on GSDP

Table V and Fig.10 reflects the contribution of service sector as percentage on GSDP. This is a very important indicator of an economy of a state. We see that compared to agriculture and industry contribution of service sector towards GSDP is the highest for all the states as well as all
India. Comparing the four eastern states West Bengal is seen to be the highest and further we see that both West Bengal and Bihar are higher than all India. Odisha is the third highest whereas Jharkhand lags behind.

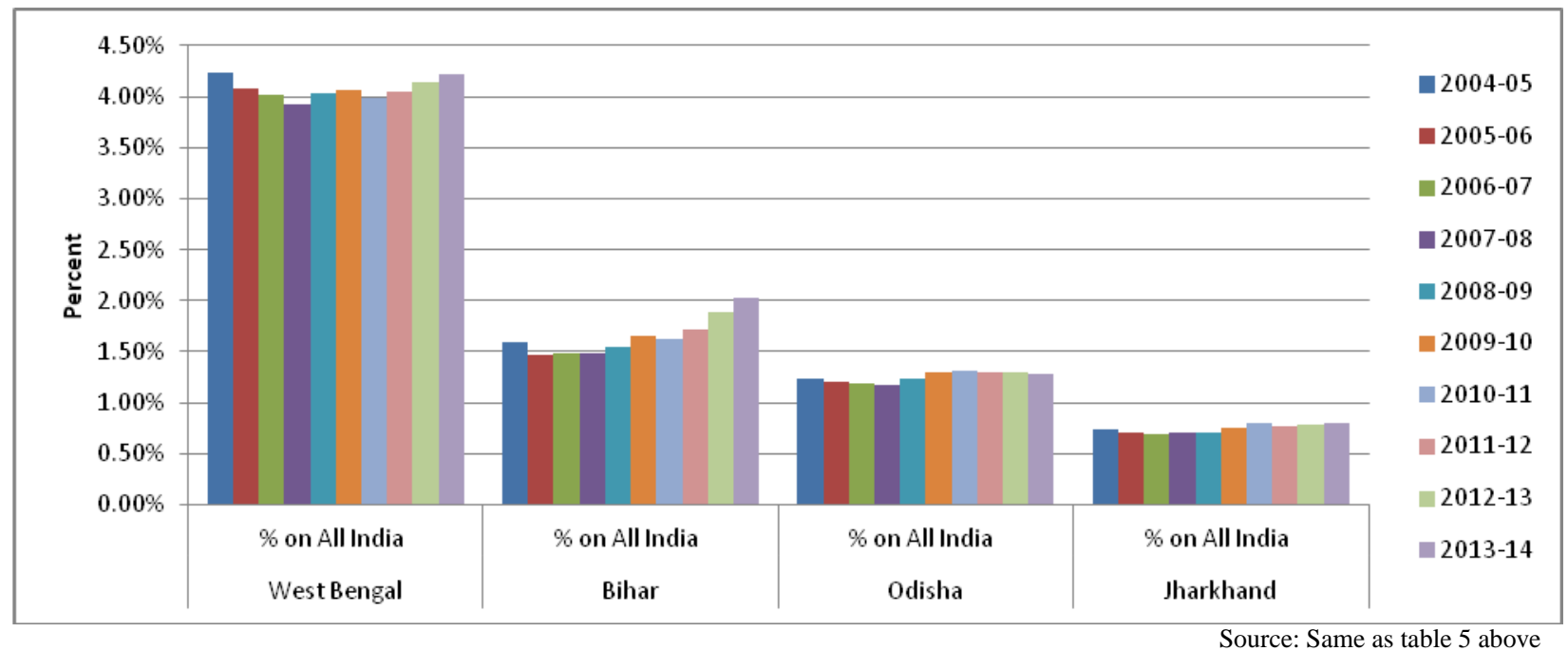

Fig. 11 Contribution of State’s Service Sector as \% on All India Service Sector

Table V and Fig.11 gives the contribution of service sector as percentage on all India service sector. Since the contribution of service sector in absolute terms was highest in case of West Bengal (Fig.6.9), in this case too West Bengal is the highest contributor of service sector as percentage on all India service sector ranging from $3.92 \%$ to $4.24 \%$.

Bihar is the highest contributing less than half of West Bengal ranging from $1.47 \%$ to $2.02 \%$. Next comes Odisha very close to Bihar contributing $1.18 \%$ to $1.32 \%$. Lastly Jharkhand is in a dismal condition not even crossing $0.80 \%$.

\section{CONCLUSION}

Based on our study certain recommendations are being given here. Regarding the demography of the states it might be mentioned that Bihar's density of population per square kilometer is the highest (1106) amongst the four eastern states. Further, the growth rate of population is also the highest $(25.5 \%)$. So, the condition of Bihar is precarious and there is every possibility of population explosion in the near future. The government of Bihar must take heed of this warning and take initiatives to impose measures for population control like increasing awareness of family planning methods, introduce rewards for single or double 
child family and impose punitive measures for families having more than two children etc. In case of Jharkhand also we see that the growth rate of population is quite high (22.5\%) but since the density of population is not very high (414), the situation is not as grim as Bihar. Yet, the government of Jharkhand must take population control seriously.

Next we come to Gross State Domestic Product (GSDP). Regarding contribution of agriculture towards GSDP it might be contented that all the states should make attempts to increase their agricultural contribution towards GSDP to, firstly, feed the growing population and, secondly, for rural employment generation. This is a sector which is not dependent on any external factors like industry and service sector, but the government's positive attitude and the endeavour of the agriculturists is sufficient for development of this agricultural sector.

The state government should take initiatives to improve infrastructural facilities in agriculture like better irrigation facilities, modern scientific technology like good quality seeds, good manures and fertilizers, herbal pesticides, efficient tractors etc., energy and power, transport and communication, construction of warehouses and cold storage, creating agricultural markets in remote villages where the agricultural produce may be sold at proper prices by the poor farmers. The government should take initiatives to construct warehouses and cold storages to store the agricultural produce letting it out to the farmers at minimum cost without any political bias, so that the farmers are not compelled to sell their produce at extremely cheap prices to the middlemen. Until we can ensure the surplus creation/profits/gains of the farmers we cannot dream of developing the agricultural sector.

Generally it is observed that the children of the farmers are sent for education to the urban cities where they get absorbed in the secondary or service sectors leaving the agricultural sector devoid of any skilled and knowledgeable class of people to guide the farmers for better agricultural production. First of all, the government should take steps to increase the number of agricultural universities in the state to increase the number of skilled and knowledgeable class of people. Further, the government must ensure greater research and development activities in the agricultural field to introduce newer technologies in this area. Thirdly, the government should set up establishments in the remote areas of cultivation where people with such specialized skill and knowledge in this agricultural field will directly or indirectly get involved in the productive activities to help the farmers for better production or to increase the productivity of agriculture. These initiatives of the government will in turn generate employment in the agricultural sector boosting the state's economy.

Regarding the contribution of Industry towards GSDP it might be contended that economic development of any state is associated with industrialisation. Through a concerted programme of industrialisation, a state can provide a basis for a rapid rate of growth of GSDP. The government should encourage industrialisation to bring about a favourable change in the state's occupational pattern. Industrialisation is the only way to the creation of employment opportunities.

In our findings we have already seen that regarding industrial contribution towards GSDP in absolute terms West Bengal is ahead of the other states but gradually it fell behind the other states like Maharashtra, Gujarat, and Tamil Nadu etc. We have seen in our findings that the growth rate of West Bengal is much lower than the other eastern states except Jharkhand, and even lower than all India. So, now the state government should try to increase the growth rate by boosting industrialisation by setting up new industries in the state. For this West Bengal government must adopt a positive industrial policy to attract investors. The government has to ensure and assure the investors that it will provide a proper investor-friendly environment for setting up industries. This means providing proper infrastructure in the form of land, transport and communication, power supply etc. To make this possible the state government should adopt a favorable land acquisition policy. Repeatedly the West Bengal government says it has a land bank but the question arises whether the land it has earmarked for industry is acceptable to the investors or not. Through a process of negotiation and compromise, the government and the investors should reach a consensus regarding the choice of land so that investors are attracted into establishing new industries. Apart from land and infrastructure, labour is also a necessary prerequisite for industrialisation. Fortunately, there is no dearth of labourers in the state. But, the government must offer certain incentives, for eg. in the form of tax reduction etc. provided in other states, so that investors are lured to set up industries in the state.

We have already iterated that economic growth depends mainly on industrial growth since agriculture has its limitations and constraints. Before bifurcation of Bihar and creation of Jharkhand the State of Bihar was rich in industry, especially in the Jamshedpur industrial belt with the Tatas at the centre of industrial activity. The creation of Jharkhand has had a colossal impact on the industrial scenario of the state. The loss of Jamshedpur left Bihar with almost no significant industries and Bihar had to start afresh in the industrial sector.

We have seen that energy and power were the main constraints of Bihar's industrial progress. The state government must adopt an alternate policy of decentralized power generation and distribution with a focus on clean, renewable energy. Bihar has considerable potential for such an approach so that the underpinning of electricity is available to build the industrial superstructure. This is a fundamental prerequisite for Bihar to move forward on the industrial front. So, the state government has to undertake a plan for renewable, decentralized power. Further, the state 
government must focus on developing small and medium enterprises because implementation of these small units will be much easier than in case of large industries. The longterm sustenance and prosperity of the state will depend on rapid economic growth on a continuous basis so that there is employment generation, social development and transformation. The state government should take initiatives to realize this vision.

The same may be recommended for the state of Odisha as well. The government must promote small enterprises which will not only generate large scale employment and ensure a high degree of self-sufficiency but will also actually help reduce inter-district disparities in growth. It is seen that the government's pro-investor policies in industrialisation has generated much interest among the private investors, both Indian large companies and transnational companies, in investing in Odisha. Hence, Odisha has emerged as one the most preferred investment destinations in India.

It might be pointed out that lack of proper infrastructure, especially transport and power, has severely impaired both growth and diversification of industries in the state. A serious rethinking on the issue of developing the energy and the power sector for the state's industrialisation is essential. Development of the neglected railways, connecting depressed regions and also mineral resources, shall activate the industrial sector. Further, the state must press for enlarging its aviation sector which should connect the main metropolitan cities including Bangalore and Ahmedabad.

As the state is endowed with a range of high-grade minerals, mere extraction, often through unscientific methods, and export in the 'raw' form have not generated adequate value added in the mining sector. Greater prospects lie in upgrading the mining activity to the status of manufacturing industry wherein mineral processing up to certain stages could be undertaken in the region. Further, due to the existence of large scale mineral-based industries, a highly promising area appears to be the engineering and machine tools industry. This, apart from creating substantial employment, would also help growth of the related service sector. Modern agro- and forest-based industries, for which there exist ample scope needs to be encouraged in the state. Thus, the state government of Odisha must continue to endeavour to accomplish rapid and sustainable industrialisation with the support of infrastructural development.

The State Government of Jharkhand is committed to maximizing capital investment in the State in order to accelerate its economic development and generate adequate employment opportunities to meet the growing aspirations of its population, particularly youth. For this the state government is determined to create a favourable destination for investment, based on the State's mineral and human resources. Development of infrastructure and power generation is the first priority in creating a favourable environment for investment.
The state of Jharkhand has immense potential for industrialization with its large deposits of minerals. But mineral-based industrial growth alone cannot cope with the employment needs of the rural population. Thus, In addition to mineral based industrialization, there is need to have rural enterprises, which will suit the rural population in terms of access to markets, know-how, funds and project implementation. About one-third of the State's area is under forest cover and it has a wide network of rivers, with power plants and industrial bases.

In order to attract investment the State Government should create a simplified clearance system for investment, including large investments. The government must simplify rules, regulations and procedures to remove bottlenecks in securing clearances for investment and establish a single window system for clearance of investment.

The State Government should also create an institutional set-up that will facilitate resolution of disputes over land acquisition, assuring a fair deal and the required rehabilitation of livelihoods of displaced households, including women and youth. All investors will be encouraged to provide skills training and then employment to persons, women and men, from households displaced by projects, particularly mega projects.

The government should, further, support entrepreneurship development through establishment of Entrepreneur Development Institute (EDI) and other specialized institutes. This should be done with a focus on improving the quality of services to small entrepreneurs with an emphasis on SC/ST, women and handicapped persons.

The government should focus on the energy and power sector in order to boost industrialisation. In addition to large power plants, promote small power generating units and develop non-conventional energy sources with private investment. The government should promote projects in Public Private Partnership (PPP) mode.

Regarding contribution of the Service sector towards GSDP it might be contended that the Service sector, also called the tertiary sector covers a wide range of activities ranging from services which are provided by different sectors. They include the most sophisticated sectors like telecommunication, satellite mapping and computer software; simple services provided by the unskilled menial workers like the barbers, the plumbers and the carpenters; highly capital intensive activities like civil aviation and shipping; employment oriented activities like tourism, real estate, and housing; infra-structure related activities like railways, roadways and ports to social related activities like health and education.

The service sector in India faces a number of hurdles. Firstly, there is want of adequate infrastructure not only in the rural areas but also in the urban areas. Our urban cities face constraints in the form of power cuts, bumpy roads, 
traffic congestion and pollution. This has a detrimental effect on the quality of services provided. The government must take steps to develop adequate infrastructure. Further, it is important to note that there are disparities in performance across states and poor states seems to do badly in services infrastructure and in delivery of public services like health and education. Policies have to focus on statewise requirements.

Secondly, tourism is a lucrative service in view of India's natural beauty and other pleasing factors, but bureaucratic delays and harassment or cheating by touts and agents act as an impending factor. The government of the states must develop a tourism policy to attract more and more tourists.

Thirdly, sincere efforts, good mannerism and etiquettes are the hallmarks of service providers but many of our banks, hotels, restaurants and hospitals are seriously lagging on this front. The problem is even more adverse in case of the public sector institutions. In this regard the government must devise ways and means to increase time-bound accountability of the service providers.

Fourthly, too many administrative procedures involved in providing various services result in various visible and invisible barriers like visa and sector specific restrictions. There is no nodal ministry at the centre for the service sector. The government should set up a regulative authority and frame favourable policies to overcome the various hurdles in this sector.

Fifthly, for the service sector to grow and have an impact on the growth process, it has to be accompanied by simultaneous developments of both the primary and secondary sectors. The government's policy focus is mainly on agriculture and industrial sectors. The state government must ensure equal importance is given to the development of all the sectors.

Sixthly, Indian service providers face stiff competition particularly Business Process outsourcing and IT providers. The state government should provide for training in skill development so that they may improve their quality to compete with the best in the world. Seventhly, since services sector is heterogeneous it is important to identify the most important barriers faced by different services subsectors and then undertake sector-specific reforms. Though the services sector is heterogeneous, different services are getting integrated due to technological developments. The government should consider this in policymaking. For example, in the case of sectors like transport and energy the different departments of the government should work together to design policy.

Lastly, it may be reiterated that in the post-liberalisation period, services sector has largely been left to grow on its own. There has been no proper regulative authority in the form of a nodal ministry to look after the service sector. But to develop this sector there must be an attempt by the government to formulate effective policies and ensure its implementation. To create quality employment in services sector the long-term focus of the government should be to encourage growth of organised sector employment and modernisation of unorganised sector. The government can work with industry and educational institutes on a publicprivate partnership basis to identify the skill requirements and to design appropriate academic courses and training programmes to facilitate skill development.

The four eastern states of India of our study have a number of problems which are socio economic in nature. Poverty and accelerated population growth are major constraints, thereby depriving several people of access to basic health and education. A number of obstacles hamper the progress of this sector and its contribution to inclusive growth. Bureaucratic inertia, multiple government bodies having their own sets of rules and regulations, rampant corruption and absence of a uniform concrete policy have an adverse effect on the system. Slow reform process, restrictions on foreign direct investment, poor infrastructural facilities, absence of uniformity in the quality and standard of education, in spite of having renowned Brain Power and the existence of unemployable educated youth are all limiting factors. India, however, has vast potential for promotion of service economy. This is attributed to factors such as emergence of a new middle class with increasing aspirations, opening of the economy leading to the availability of a wide range of goods and services, growing retail and improving domestic and international market for Information Technology.

\section{REFERENCES}

[1] Ross Mallick. "Development Policy of a Communist Government: West Bengal Since 1977”, Cambridge University Press, Cambridge (Reprinted 2008) ISBN 978-0-521-43292-4, 1955.

[2] Marvin, Davis, "Rank and rivalry: the politics of inequality in rural West Bengal”, Cambridge: Cambridge University Press. pp. xxvii, 239. ISBN 0-521-24657-1, 1983.

[3] Atul Kohli, I., "The State and Poverty in India”, Cambridge University Press. ISBN 978-0-521-37876-5. Retrieved 16 June 2007.

[4] Richard Maxwell Eaton, "The rise of Islam and the Bengal frontier", pp. 1204-1760, 1993, University of California Press, California, California, 1993, ISBN 0-520-08077-7, 1987.

[5] Acharya, Niru and Srithi Acharya, "Structural Adjustments and Small Producers: Reflections from Case Studies”, Economic and Political Weekly, Vol. XXX, No. 1(January), pp. 45-46, 1995.

[6] Dreze J. and A. Sen, "India: Economic Development and Social Opportunity”, Oxford University press, 1995.

[7] Das, S. K. and A. Barua, "Regional Inequalities, Economic Growth and Liberalisation: A Study of the Indian Economy”, Journal of Development Studies, Vol. 32, No. 3, pp. 364-91, February, 1996.

[8] Hindle, Jane, ed., "London Review of Books: An Anthology", Foreword by Alan Bennett. London: Verso. pp. 63-70. ISBN 185984-121-X, 1996.

[9] L. Klass, S. Morton, "Community Structure and industrialization in West Bengal”, University Press of America Inc. ISBN 0-7618-0420X, 1996.

[10] V. Amrita Basu, "Two Faces of Protest: Contrasting Modes of Women's Activism in India”, University of California Press ltd. ISBN 0-520-06506-9. Retrieved 16 June 2009.

[11] Baxter, Craig, "Bangladesh: From a Nation to a State. Boulder", Colorado: Westview Press. ISBN 1-85984-121-X, 1997. 
[12] Banerjee, Anuradha , "Environment, population, and human settlements of Sundarban Delta”. Ashok Kumar Mittal. ISBN 817022-739-9, 1998.

[13] Datt, G. and M. Ravallion, "Why Have Some Indian States Done better than Others at Reducing Rural Poverty?”, Economica, Vol. 65, pp. 17-38, 1998.

[14] C. Sunny, "Poverty and social development in west bengal" (PDF). India Rural Development Report, NIRD, 1999.

[15] Jasodhara Bagchi, V. Sarmistha Dutta Gupta, "The changing status of women in West Bengal, 1970-2000: the challenge ahead”, Saga Publication India Pvt Ltd. ISBN 0-7619-3242-9, 2000. Retrieved 16 June 2010.

[16] G. Datt, and M. Ravallion, "Why has economic growth been more pro-poor in some states of India than others?", Journal of Development Economics, Vol. 68, pp. 381- 400, 2002.

[17] Tapan Raychaudhuri., "Europe Reconsidered: Perceptions of the West in Nineteenth-Century Bengal”, Oxford University Press. ISBN 978-0-19-566109-5, 2002.

[18] A. Bhuimali, "Rural Cooperative and Economic Development". Sarup \& Sons, New Delhi, 2003.

[19] Roy, Ananya, AlSayyad, Nezar, "Urban Informality: Transnational Perspectives from the Middle East, Latin America, and South Asia”. Lanham, Md: Lexington Books. ISBN 0-7391-0741-0, 2004.

[20] "West Bengal Human Development Report, (PDF)", Kolkata: Development and Planning Department, Government of West Bengal. May 2004. ISBN 81-7955-030-3.

[21] Bhuimali Anil and Kanak Kanti Bagchi, "Resource-Industry Linkages in Sikkim : Strategy of Development in the context of Structural Change" in Structural Change and Strategy of Development : Resource-Industry Linkages in North East India, Gurudas Das (Ed), Akansha Publishing House, New Delhi, pp. 187-206, 2005.

[22] Inden, B. Ronald, W Ralph, "Kinship in Bengali Culture”, The University of Chicago Press, 1977. ISBN 81-8028-018-7, 2005.

[23] Raychaudhuri, Ajitava (editor); Das, Tuhin K. (editor), "West Bengal economy: some contemporary issues”, Jadavpur University Press, India. ISBN 81-7764-731-8, 2005.

[24] A. Ali, S. Nayak, and S. Mukhopadhya, "State of Health in Bihar". Population Foundation of India, 2007.

[25] KPMG in India. "Sustainable economic development in West Bengal - A Perspective" (PDF). Confederation of Indian Industry (CII), 2007.

[26] Harriss-White, Barbara (editor) "Rural Commercial Capital: Agricultural Markets in West Bengal”, Oxford University Press, USA. ISBN 0-19-569159-8, 2008.

[27] Magnus Öberg, V. Kaare Strom, "Resources, governance and civil conflict”. Routledge. ISBN 978-0-415-41671-9, 2008. Retrieved 16 June 2004.
[28] "Impact of Social Sector Development in West Bengal. Planning Commission”, Government of India. 2009.

[29] Pranab Chatterjee, "A Story of Ambivalent Modernization in Bangladesh and West Bengal: The Rise and Fall of Bengali Elitism in South Asia”, Peter Lang Publishing; First printing edition. ISBN 9781-4331-0820-4, 2009.

[30] S.S. A Aiyar, "Bihar's economic miracle: real, but fragile". The Economic Times. 21st February, 2010

[31] Ghosh, P. P. and Shaibal Gupta, "Economic growth and human development in Bihar" in Backwaters of development: Six deprived states of India, Shovon Ray (Ed), OUP: India, 2010.

[32] Acemoglu, D. and J. A. Robinson, "Why nations fail: The Origins of Power”, Prosperity and Poverty. Profile Books Ltd. London, 2012

[33] S. Bandyopadhyay, and Anasua Basu Ray Chaudhuri, "In Search of Space: The Scheduled Caste Movement in West Bengal after Partition”, Policies \& Practices. Mahanirban Calcutta Research Group. Vol. 33, pp. 3-8, 2012.

[34] G.S. Bhalla, and G. Singh, "Economic Liberalisation and Indian Agriculture: A District Level Study”, Sage Publications, New Delhi, 2012.

[35] Government of West Bengal, Law Department, Lagislative Notification. No. 182- L - 24 January 2013. West Bengal Act XXXVI of 2012. The West Bengal Official Language (Second Amendment) Act, 2012.

[36] N.K Singh and Nicholas Stern, "The New Bihar- Rekindling Governance and Development”, HarperCollins Publishers India, Noida,U.P, 2013.

[37] A. Bhuimali, and Mukul Saha, "Development Issues in the East and North-East States of India”, Journal of Rural and Community Affairs. Vol. 1, pp. 26-49, 2015.

[38] http://www.onefivenine.com/india/villag/state/Bihar

[39] http://gov.bih.nic.in/Profile/history.htm\#pagetop

[40] http://www.thisismyindia.com/bihar/economy.htm

[41] https://www.quora.com/Why-was-Jharkhand-separated-from-Bihar

[42] https://www.google.co.in/search?q=map+of+west+bengal

[43] https://www.rbi.org.in/scripts/AnnualPublications.aspx?head=State\% 20Finances\%20:\%20A\%20Study\%20of\%20Budgets

[44] file://C:/Users/User/Desktop/Reserve\%20Bank\%20of\%20India\%20\%20Handbook\%20of\%20Statistics\%20on\%20Indian\%20States_files/ Reserve\%20Bank\%20of\%20India\%20\%20Handbook\%20of\%20Statistics\%20on\%20Indian\%20States.html

[45] https://www.rbi.org.in/scripts/OccasionalPublications.aspx?head=Ha ndbook+of+Statistics+on+State+Government+Finances++2010.https://www.rbi.org.in/scripts/PublicationsView.aspx?id=1488 7file://C:/Users/User/Desktop/Databank-resources.html(RBI State Finance)

[46] https://rbi.org.in/SCRIPTs/PublicationsView.aspx?id=17003 